\title{
A brief history of agri-environment policy in Australia: From community-based NRM to market-based instruments
}

\section{David Salt}

\section{Key lessons}

- Australia's agri-environment policy began in the 1980s. Early measures focused on community-based NRM, increasing awareness, and building social capital through Landcare.

- The perceived success of these early efforts enabled a ramping up of government investment through the Natural Heritage Trust and successive programs.

- There have been repeated failures to demonstrate measurable outcomes from this increased investment.

- This has led to a greater focus on targeted, strategic, and accountable programs.

- The capacities required to effectively deliver these programs have been inadequately addressed. 


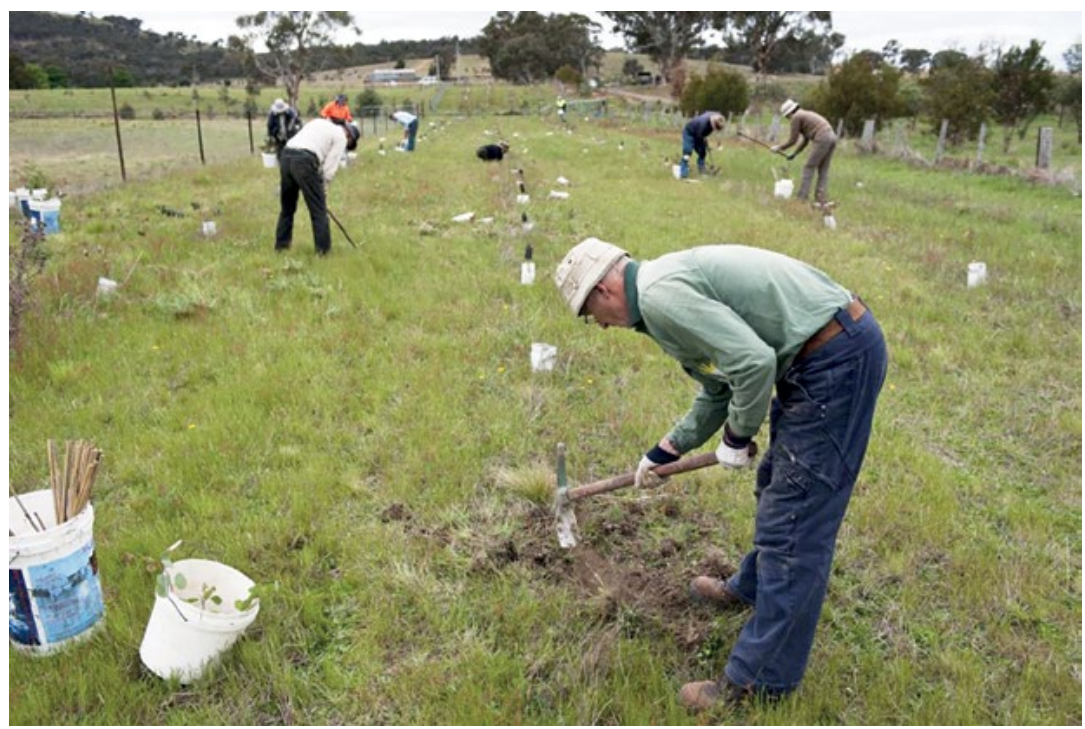

Figure 7.1: Early measures in agri-environment policy focused on community-based NRM.

Source: Photo by Greening Australia.

\section{A very brief history}

A very brief history of agri-environment policy in Australia would read something like this: It began back in the 1980s. It started small and focused on engaging the community and building capacity. It rested heavily on a volunteer effort. Initial efforts were well received and the size of the investment grew during the 1990s. However, despite increased levels of investment, agri-environment programs failed to produce enduring environmental outcomes. This failure has led more recent programs to focus on specific environmental assets through the application of a suite of market-based instruments (MBIs).

It sounds pretty dry when summarised like this, but the bottom line is that agri-environment schemes in Australia have not improved biodiversity or reversed the ongoing degradation of land and water resources. Farming is the country's major land use, it always has been, and Australia's governments have invested significant amounts of money in programs in our agricultural landscapes - most commonly referred to in the literature as agri-environment programs - that aim 
to reverse these declines. To date, after spending well over $\$ 6.5$ billion, this investment hasn't produced many enduring environmental outcomes (Hajkowicz 2009).

This chapter seeks to expand on this very brief history. It will discuss the rise of the agri-environment and the widespread concern that investments in this space are not working. It will also touch on the counter view that the greater targeting and the complementary use of market instruments to deliver this investment may be sacrificing some of the gains made in earlier rounds.

\section{The emergence of the agri-environment}

While the literature talks about agri-environment policy, the term 'agri-environment' is not one you'll hear much out on any Australian farm. It's a description that originated in Europe as part of the Common Agricultural Policy (see Chapter 6 by Rob Fraser). Anecdotal feedback suggests Australian farmers regard the notion of agri-environment as 'smelling a bit Euro' (conveying a widespread feeling in the Australian agricultural sector that European farming receives too much government support and protection).

In Australia, the term more commonly used is 'natural resource management' (NRM), though this term is unacceptably broad for our purposes as it covers a wide range of issues that fall well outside of the farming landscape (e.g. the management of national parks). So, in this chapter (and this book), we keep with the term 'agri-environment' and use it mainly as an adjective describing government investment in environmental programs on agricultural land. But the agri-environment is also a concept embodying the notion that our agricultural lands aren't just about the production of saleable commodities (e.g. food and fibre). They are also a space that provides a range of ecosystem goods and services that are valued by the broader public (e.g. biodiversity and rural amenity).

When did the agri-environment emerge? Well, of course, it's always been there in terms of our rural landscapes being valued for multiple purposes, not just production (Watson 2014). Indeed, over the past 
century the relative economic value of our agricultural lands has declined from 20 per cent of Australia's GDP in 1901 to less than 3 per cent in recent years (Hajkowicz 2009).

However, it was during the 1980s that Australian governments, and particularly the federal government, began investing considerable amounts into these landscapes to protect these multiple values, moving from a purely commodity-based industry to one that included social, economic, and environmental outcomes (Clayton et al. 2011).

Why then? There are many drivers behind this shift away from a single focus, but the 1980s was a time of many international and national conversations on conservation (with a World Conservation Strategy released in 1980, followed by a National Conservation Strategy for Australia in 1983) and sustainability (with the release of the groundbreaking Brundtland Report in 1987).

The notion of sustainability was brought to the fore particularly in Australia with a historic drought ravaging our production landscapes. The connection between land degradation and sustainable production was given a high profile. Of course, dealing with environmental degradation was not a new thing in 'the land of droughts and flooding rains', and state governments had been establishing soil conservation committees to address soil erosion from the 1930s (just as the US established the Soil Conservation Service following the dust-bowl years). But it wasn't until 1983 that the Commonwealth Government established an overarching process: the National Soil Conservation Program. This program undertook research, and provided advice and extension, with the aim of achieving cooperation between community, farmers, and government (Curtis et al. 2014). Starting from a small base, funding grew over the program's life with over $\$ 10$ million being spent in its final year of 1988/99 (Hajkowicz 2009).

In addition to a growing national focus on how to deal with land degradation and conservation, the 1980s also saw community networks in the form of Landcare groups emerging in Victoria and Western Australia (with state government support). These networks facilitated education, raised awareness, and catalysed activities on the ground. Towards the end of the 1980s, an unprecedented alliance between the conservation lobby (the Australian Conservation Foundation) and the farmer lobby (the National Farmers Federation) proposed a Decade 
of Landcare, in which community action would raise awareness and catalyse investment to repair and nurture the land (Curtis and De Lacy 1998). The Australian Government accepted the proposal, and in 1989 announced the funding of $\$ 360$ million for a Decade of Landcare. The Landcare movement emphasised local responses to landscapewide challenges of national concern. It was hailed internationally as a remarkable initiative.

The National Landcare Program initially ran as part of the National Soil Conservation Program. Between 1990 and 1996 it was run as an independent program, and then through to 2008 as a subprogram of the Natural Heritage Trust. The National Landcare Program officially concluded in 2008, and has recently been resurrected by the current federal government. All of which reflects the patchwork history of this national program.

There was significant enthusiasm around the vision of Landcare. Local groups were encouraged to self-organise around land and water issues, with small amounts of short-term funding. The aim was to harness community spirit and catalyse greater investment from a number of sources rather than for government to provide most of the funding itself (Tennent and Lockie 2013). The approach proved popular: within five years of being established the movement had expanded from 200 local Landcare groups to 2,200 (Martin and Woodhill 1995). By 2004, there were some 4,500 groups, consisting of around 120,000 volunteers, including 30 per cent of farmers. Some surveys even recorded that farmers who did not join Landcare groups believed that their properties had benefited from participation in Landcare activities (Curtis and De Lacy 1996, and see 'Evolution of Landcare in Australia': www.agriculture.gov.au/ag-farm-food/natural-resources/ landcare/publications/evolution-of-landcare-in-australia).

\section{Ramping up investment}

The National Landcare Program signalled a significant increase in investment and interest in NRM across Australia. This ramp up in investment paralleled large increases in investment in NRM in the United States and the European Union (EU), albeit Australia was spending a fraction of the amounts they were investing (Hajkowicz 2009). Around the world there was a growing societal concern about 
environmental degradation, much of which was (and still is) connected to the intensification of agricultural production, and societal permission for farmers to be paid for the public good of environmental outputs. In the EU and the United States, these environmental payments were offered as an alternative way to continue government support to farmers, but in a manner that didn't distort production or harm international trade.

But the situation was different in Australia. At the end of the 1980s, the Australian Government wasn't supporting farmers to the same degree as in the United States or the EU, and there was little trade protection on offer. This reflected Australia's smaller population (and therefore smaller tax base) and considerably smaller agricultural sector. Yet the actual size of our agricultural estate is comparable to these other regions.

The Australian Government simply didn't have the available resources to protect and subsidise agriculture in the manner in which agriculture was supported in the EU and the United States. In Australia's case, it wasn't a matter of attempting to wean farmers off existing support. Because there was little existing support in Australia, there was no pool of funds available, as was the case in the United States and the EU. However, there was a common growing societal concern (from both the city and the country) about the environmental costs of agriculture.

Landcare was an impressive achievement, and yet it was soon realised that building networks, raising awareness, and changing attitudes was not enough by itself. Significantly greater investment was required if Australia was to effectively tackle the multiple problems of soil erosion, water degradation, and biodiversity decline (Curtis 2000; Hajkowicz 2009).

What Landcare did demonstrate, however, was that government funding for environmental activity in regional Australia enjoyed widespread electoral support. Indeed, when the Australian Government controversially sold the national telecommunications company Telstra in 1997, it dedicated $\$ 1.3$ billion from the sale towards a new national NRM program called the Natural Heritage Trust (NHT). This represented a quantum leap in NRM, received 
widespread community support (Curtis et al. 2014), and went some way to assuaging the electorate's concerns about the sale of a large public asset such as Telstra.

On paper it was a win-win - a means of providing support to an important constituency (the farming sector) in a politically acceptable fashion (payments for the environment) that would produce dividends for everyone (a healthier, productive landscape).

The only problem was that the promised environmental outcomes could not be measured. This was pointed out to the government by Australia's national auditors on several occasions (see ANAO 2008 for a summary). The NHT was subsequently described as suffering from the Vegemite approach (a uniquely Australian description). ${ }^{1}$ In other words, the investment was spread too wide and too thinly to produce changes that could be readily observed.

\section{NRM evolution}

The billion-dollar NHT didn't counter the growing environmental threats facing Australia's agricultural landscapes, indeed, what it had achieved couldn't even be measured. What it did do, however, was set a benchmark for what the nation expected to be spent on environmental programs across our production zones.

Following the NHT, four national NRM programs were rolled out over the following decade: a second round of the Natural Heritage Trust (NHT2), the National Action Plan for Salinity and Water Quality (NAP), Caring for our Country (CfoC), and, most recently, a new version of the National Landcare Program. At the time of writing, this new National Landcare Program is still being formulated, so it won't be discussed here. Each program was sold as a billion-dollar (plus) fix that would halt environmental decline and ensure the productive future of our agricultural landscapes. Figure 7.2 outlines the amounts committed to each program.

\footnotetext{
1 For non-Australian readers, it should be pointed out that Vegemite is an Australian food product: a black, oily, salty spread for toast and bread.
} 


\section{The evolution of Australian NRM programs}

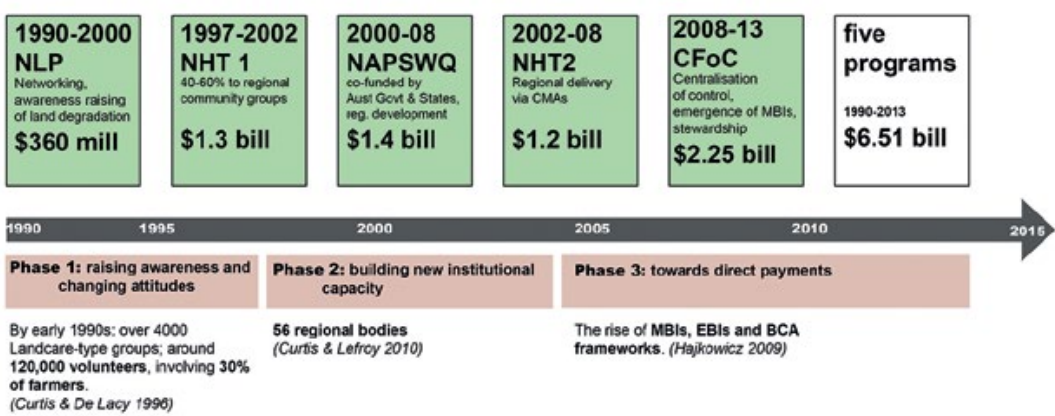

Figure 7.2: The evolving focus of Australian NRM programs.

Source: Modified from Hajkowicz 2009.

Figure 7.2 summarises the five major NRM programs that have been rolled out in Australia over the past quarter of a century. Together they have resulted in a total of over $\$ 6.5$ billion in expenditure. Stefan Hajkowicz frames this roll out as an evolution that proceeded through three phases (Hajkowicz 2009). He labelled these as awareness raising (phase one), building institutional capacity (phase two), and towards direct payments (phase three). This categorisation has proved quite popular in the academic literature, with several authors using it as a frame for their own examination of this period. (For excellent accounts of the history of NRM investment policy in Australia see Morrison et al. 2010; Clayton et al. 2011; and Tennent and Lockie 2013, all of which use the categorisation described by Hajkowicz).

In broad brush strokes, phase one marks the birth of communitybased NRM through the establishment and growth of Landcare, and the ramp up of environmental spending to billion-dollar programs.

Phase one elevated community-based NRM to centre stage and met with strong electoral support. But it didn't address the environmental degradation that prompted it. Phase two saw an effort to respond to criticisms that these earlier investments, while changing attitudes and building social networks, weren't achieving improvements in resource conditions. Problems of salinity, soil erosion, water pollution, and biodiversity decline seemed to continue unabated. In response, 
a greater focus was placed on strategy and regional delivery with program funding being delivered via regional catchment management authorities (CMAs).

Phase two saw the development of regional bodies to better target the investment to regional needs while assisting in the delivery of resources in a more strategic manner.

In 2000, the Australian Government released a new NAP and in 2002 the next version of the NHT. Both were to be delivered by these regional bodies, with funding being dependent on proposals aligning with regional plans. The regional scale was considered appropriate to support NRM, as it is holistic and comprehensive (Curtis et al. 2014). It was expected that this regional empowerment would be complementary to Landcare, which still operated at the local level.

Phase three saw NHT2 being replaced by $\mathrm{CfoC}$, with the Australian Government adopting a more centralised, strategic, and competitive approach to NRM. A key component of this approach involved direct payments to farmers through MBIs. For several years, Australian Governments had been experimenting with MBIs, with a focus on reverse auctions in which farmers were asked to tender for the provision of specified environmental actions and the government selected those bids that gave them greatest value for their money. (This was the manner in which money was given out for the Environmental Stewardship Program, described in Chapter 3.) Some claim MBIs are an effective and efficient way to allocate resources (e.g. Stoneham et al. 2003). Others are worried that the claims of efficacy and cost-effectiveness have not been substantiated, and that we don't yet have functioning markets for environmental services (Curtis and Lefroy 2010).

\section{Evolution or devolution?}

Viewed as a phased progression, as set out by Hajkowicz (2009), it might be said that NRM policy in Australia has grown more sophisticated and efficient over its 25-year history, harnessing a wider range of tools and players; that each phase has developed new strategies and capacities that have underpinned subsequent investments. Community awareness and social capital developed in 
the first phase complemented (and underpinned) growing regional capacity and strategy development in the second phase. The roll out of MBIs guided by various environmental benefit indexes in phase three builds on top of the community capacity building of phase one and regional capacity building of phase two.

Indeed, Hajkowicz's progression finishes with the promise of the delivery of a new Environmental Stewardship Program as part of CfoC that will target 'matters of significant interest' (e.g. threatened ecosystems) through direct payments to farmers which will result in contracts that last up to 15 years - significantly longer than earlier schemes and more in accord with time frames of the ecological processes the scheme is attempting to protect (see Chapter 3 by Emma Burns and colleagues for a summary of the Environmental Stewardship Program). Promoting the scheme and collecting information on the suitability of bids would be done in conjunction with the regional CMAs, and there were significant resources put aside for monitoring and evaluation of those bids that ended up receiving contracts. In many ways, this confirms the suggestion of an evolution of policy that is learning and improving with each successive round.

Yet there is a growing counter view as well, suggesting that the earlier achievements made through Landcare and the development of regional delivery have been forgotten, and that the stocks of human and social capital that were developed during these earlier times have been degraded and lost. Some have suggested that our drive for efficiency may have come at the cost of effectiveness (Curtis and Lefroy 2010). Several audit reports on national NRM programs have pointed out that a lack of monitoring of outcomes and a focus on outputs rather than outcomes has made it impossible to determine whether this new approach is working (ANAO 2008, 2014).

Evidence has emerged of declining membership in community Landcare groups in parts of Western Australia, Victoria and New South Wales. Volunteer burn out has been reported in many places, with many community Landcare groups in sleeper mode or ceasing to exist (Tennent and Lockie 2013). One of the designers of Landcare recently described the program as little more than 'a threadbare patchwork quilt of tired volunteers, waiting for the next government program with a new website, a new logo, a new departmental name, and less money than it had before' (Bush Telegraph 2014). 
When NHT2 and NAP were rolled out, support for Landcare was supposed to flow through the regional CMAs: Landcare provided the grass-roots knowledge, volunteers and connections; CMAs provided the regional targets, strategy and expert knowledge. But the experience in many places was of competition and displacement rather than complementarity and cooperation.

With $\mathrm{CfoC}$, the regional CMAs found their role in the delivery of community-based NRM constrained, with a reduction in base funding, increased competition with a wider range of organisations, increased transaction costs, and the need to align projects to national priorities. In some cases, regional bodies redirected support away from Landcare support, cutting the available workforce in Victoria, as one example, by more than half (Curtis et al. 2014). At the same time, state governments were making large cuts to NRM expenditure across Australia, translating to a $40-50$ per cent reduction in funding to regional bodies in New South Wales and Victoria (Curtis et al. 2014).

It seemed to some observers that while the government had been devolving responsibility to regions and local groups to affect landscape change, it hadn't been passing down the authority or agency, or even the necessary resources, to underpin the required effort (Wallington et al. 2008). Indeed, given the lack of measurable outcomes from previous investment in community-based NRM, it has been suggested that governments were introducing MBIs as a way of controlling farmers' behaviour.

This raises a major tension. On the one hand, a collaborative approach is still held up as an important dimension of NRM funding and management - that investment should cultivate and work through partnerships between individuals (farmers), groups (Landcare), regions (CMAs), and government (state and federal). Indeed, such an approach is consistent with the government's neoliberal agenda of shifting responsibilities from governments to communities and individuals. However, on the other hand, this evolution has seen the original intent of empowering communities changing to one where these bodies have simply become on-ground implementation agents of strategies decided elsewhere, largely within a centralised government (Lockwood and Davidson 2010). 


\section{The baby and the bathwater}

This brings us back to our very brief history of agri-environment policy. Agri-environment policy began in the 1980s as an effort to arrest declining environmental conditions in our agricultural landscapes. It took off as a partnership, and sought to empower communities and regions. But it didn't fix the things it was set up to fix, so, over the years, it progressively moved the emphasis from empowerment to targeted grants focused on specific environmental assets. It switched from building adaptive capacity and raising awareness, which is extremely hard to quantify and measure, to a focus on investing in specific actions on definable things. It moved from cultivating an ethic rooted in collaboration, sharing, and volunteerism to a culture of benefit-cost analysis and fee for service. We are much better placed to define and measure what we should be doing, but have lost sight of the suite of community capacities that enable those actions to be effectively undertaken.

Australia is currently seeing the roll-out of a new national billiondollar program named the National Landcare Programme, which will involve planting many trees (the target is 20 million), a Green Army (to establish on-ground works while training young and unemployed Australians), and speaks the rhetoric of empowering regional Australia. Whether it succeeds or sustains our track record of failure will likely depend on whether we have the capacity to learn from our quarter of a century of effort in the agri-environment space.

\section{References}

Australian National Audit Office (ANAO) (2008) Regional Delivery Model for the Natural Heritage Trust and the National Action Plan for Salinity and Water Quality, Australian National Audit Office Audit Report No. 21, 2007-08. Available at: www.anao.gov.au/ uploads/documents/2007-08_audit_report_21.pdf.

ANAO (2014) Administration of the Biodiversity Fund Program, Australian National Audit Office Audit Report No. 10, 2014-15. Available at: www.anao.gov.au/ /media/Files/Audit\%20Reports/ 2014\%202015/Report\%2010/AuditReport_2014-2015_10.pdf. 
Barr, N. (2009) The house of the hill: The transformation of Australia's farming communities, Land and Water Australia, Canberra.

Bush Telegraph (2014) 'Spirit of Landcare is "lost", ABC Radio National. Available at: www.abc.net.au/radionational/programs/ bushtelegraph/landcare-funding/5455356.

Clayton, H., S. Dovers and P. Harris (2011) HC Coombs Policy Forum NRM initiative, The Australian National University, Canberra. Available at: crawford.anu.edu.au/public_policy_community/ research/nrm/NRM_Ref_Group_Combined.pdf.

Curtis, A.L. (2000) 'Landcare: Approaching the limits of voluntary action', Australian Journal of Environmental Management 7: 19-27.

Curtis, A. and T. De Lacy (1996) 'Landcare in Australia: Does it make a difference?', Journal of Environmental Management 46: 119-37.

Curtis, A. and T. De Lacy (1998) 'Landcare, stewardship and sustainable agriculture in Australia', Environmental Values, 7: 59-78.

Curtis, A.L. and E.C. Lefroy (2010) 'Beyond threat- and assetbased approaches to natural resource management in Australia', Australian Journal of Environmental Management 17: 134-41.

Curtis A., H. Ross, G.R. Marshall, C. Baldwin, et al. (2014) 'The great experiment with devolved NRM governance: Lessons from community engagement in Australia and New Zealand since the 1980s', Australasian Journal of Environmental Management 21(2): 175-99.

Hajkowicz, S. (2009) 'The evolution of Australia's natural resource management programs: Towards improved targeting and evaluation of investments', Land Use Policy 26: 471-8.

Lockwood, M. and J. Davidson (2010) 'Environmental governance and the hybrid regime of Australian natural resources management', Geoforum 41(3): 388-98.

Martin, P. and J. Woodhill (1995) 'Landcare in the balance: Government roles and policy issues in sustaining rural environments', Australian Journal of Environmental Management 2(3): 173-83. 
Morrison, T., C. McAlpine, J. Rhodes, A. Peterson and P. Schmidt (2010) 'Back to the future?: Planning for environmental outcomes and the new Caring for our Country program', Australian Geographer 41(4): 521-38.

Pannell, D.J. and A.M. Roberts (2010) 'Australia's National Action Plan for Salinity and Water Quality: A retrospective assessment', Agriculture and Resource Economics 54: 437-56.

Stoneham, G., V. Chaudhri, A. Ha and L. Strappazzon (2003) 'Auctions for conservation contracts: An empirical examination of Victoria's BushTender trial', Australian Journal of Agricultural and Resource Economics 47: 477-500.

Tennent, R. and S. Lockie (2013) 'Vale Landcare: The rise and decline of community-based natural resource management in rural Australia', Journal of Environmental Planning and Management 56(4): 572-87.

Wallington, T., G. Lawrence and B. Loechel (2008) 'Reflections on the legitimacy of regional environmental governance: Lessons from Australia's experiment in natural resource management', Journal of Environmental Policy and Planning 10(1): 1-30. DOI:10.1080/15239080701652763.

Watson, D. (2014) The Bush: Travels in the heart of Australia, Penguin Books, Ringwood. 
This text is taken from Learning from agri-environment schemes in Australia: Investing in biodiversity and other ecosystem services on farms, edited by Dean Ansell, Fiona Gibson and David Salt, published 2016 by ANU Press, The Australian National University, Canberra, Australia. 